\title{
ANALISIS PENGARUH SIKAP GENERASI MILENIAL TERHADAP MINAT MELAKUKAN USAHA TANI DI DESA LAPODI KECAMATAN PASARWAJO KABUPATEN BUTON
}

\author{
Suriadi $^{1}$, Rabiyatul Jasiyah ${ }^{2}$, Gafaruddin ${ }^{3}$ \\ Program Studi Agribisnis, Fakultas Pertanian \\ Universitas Muhammadiyah Buton \\ Jl. Betoambari No. 36 Baubau \\ yadisuriadi1969@gmail.com
}

\begin{abstract}
This study aims to determine the effect of the attitude of the millennial generation on the interest in farming in Lapodi village. This research was conducted in Lapodi village, Pasarwajo sub-district, Buton regency from February to March 2020. The sample of this research is all millennial farmers in Lapodi village with a total of 44 people. The technique of collecting data is using a questionnaire. The data analysis technique uses multiple linear regression analysis, with the help of the SPSS 16.0 application. In the SPSS application, the analysis used is the validity test, reliability test, normality test, $t$-sample test, ANOVA, coefficients, and r-square test. The results showed that the attitude of the millennial generation had a significant effect on the interest in doing agricultural business, this can be seen from the results of the SPSS printout where $T_{\text {count }}=2,850>T_{\text {table }}(0,05)=2,000$. Thus HO is rejected and $\mathrm{HI}$ is accepted, which states that the higher the attitude of the millennial generation to do agricultural business. The influence of the attitude of the millennial generation on the interest of agricultural enterprises of $40.3 \%$ while $59.7 \%$ is influenced by other factors that are not included in this research model.
\end{abstract}

Keywords: Millennial generation, attitudes, interests farming

\begin{abstract}
Abstrak
Penelitian ini bertujuan untuk mengetahui pengaruh sikap generasi millennial terhadap minat usaha tani di Desa Lapodi. Penelitian ini dilakukan di Desa Lapodi Kecamatan Pasarwajo Kabupaten Buton. Penelitian ini dilaksanakan pada bulan Februari sampai dengan Maret 2020. Sampel penelitian ini adalah seluruh petani millennial di Desa Lapodi dengan jumlah 44 orang. Teknis pengumpulan data adalah menggunakan kuesioner. Teknis analisis data menggunakan analisis regresi linear, dengan bantuan aplikasi SPSS 16.0. Pada aplikasi SPSS, analisis yang digunakan yaitu uji validitas, uji reliabilitas, uji normalitas, uji t-sample test, ANOVA, coefficients, dan uji r-square. Hasil penelitian menunjukkan bahwa sikap generasi millennial berpengaruh signifikan terhadap minat dalam melakukan usaha pertanian, hal ini dilihat dari hasil print out SPSS dimana t-hitung $=2,850>\mathrm{t}$-tabel $(0,05)=2,000$. Dengan demikian H0 ditolak dan H1 diterima yang menyatakan semakin tinggi sikap generasi millennial terhadap pertanian maka semakin tinggi pula minat generasi millennial untuk melakukan usaha pertanian. Pengaruh sikap generasi millennial terhadap minat usaha pertanian sebesar 40,3\% sedangkan sebesar 59,7 \% dipengaruhi oleh faktor lain yang tidak terdapat dalam model penelitian ini.
\end{abstract}


Kata Kunci: sikap generasi millennial, minat, usaha tani.

\section{PENDAHULUAN}

\section{Latar Belakang}

Pangan sering menjadi masalah yang serius dan menjadi perdebatan hangat di masyarakat Indonesia, lebih-lebih masalah itu disorotkan kepada pihak pemerintah selaku yang dianggap paling bertanggung jawab terhadap pemenuhan kebutuhan masyarakat. Penduduk yang terus bertambah, konsumsi pangan yang tinggi, tanpa diimbangi produksi pangan dalam negeri menyebabkan keadaan yang memaksa pemerintah untuk mengimpor segala kebutuhan. Ketersediaan bahan pangan yang lebih kecil dibandingkan kebutuhan masyarakat dapat menciptakan ketidakstabilan ekonomi. Berbagai gejolak ekonomi, sosial dan politik-pun dapat terjadi jika ketahanan pangan terganggu. Bukan tidak mungkin masalah pangan menjadi suatu ancaman yang serius bagi kehidupan di masa datang, karena itu diperlukan peran aktif masyarakat dalam mengelola usaha pertanian, termasuk mendorong minat generasi millennial untuk melakukan usaha tani sehingga ketersediaan pangan dan kestabilan ekonomi di sektor pertanian tetap terjaga. Dalam Undang - Undang Nomor 18 Tahun 2012 Tentang Pangan menyebutkan bahwa "Ketahanan Pangan adalah kondisi terpenuhinya pangan bagi Negara sampai dengan perseorangan, yang tercermin dari tersedianya pangan yang cukup, baik jumlah maupun mutunya, aman, beragam, bergizi, merata, dan terjangkau serta tidak bertentangan dengan agama, keyakinan, dan budaya masyarakat, untuk dapat hidup sehat, aktif, dan produktif secara berkelanjutan".

Usaha tani merupakan kegiatan yang berkaitan dengan pengelolaan dan pemanfaatan sumber daya alam, permodalan, tenaga kerja, dan skill lainnya untuk menciptakan suatu produk pertanian secara efektif dan efisien, serta mendapatkan keuntungan, sebagaimana pendapat Soekarwati (2011) bahwa "usaha tani adalah ilmu yang mempelajari bagaimana mengalokasikan sumber daya yang dimiliki petani agar berjalan secara efektif dan efisien dan memanfaatkan sumber daya tersebut agar memperoleh keuntungan yang setinggi-tingginya". Namun dalam hal melakukan kegiatan usaha tani sangat banyak persepsi yang sudah melekat pada usaha pertanian, seperti miskin, resiko kerugian besar, kesan tidak keren, kotor dan lainlain. Petani sering mengalami kerugian pasca panen. Penyebabnya entah karena bibit yang digunakan tidak unggul, penggunaan pupuk dan pestisida yang tidak sesuai, ataupun karena organisme pengganggu tanaman yang menjadikan pertumbuhan tanaman menjadi tidak baik. Bahkan ada pula untuk modal menggarap lahan harus meminjam uang kepada rentenir yang bunganya cukup besar. Belum sampai masa panen mereka harus membayar uang tersebut, dan itu menyulitkan bagi mereka.

Karena itu sebahagian dari generasi millennial lebih memilih profesi lain atau pekerjaan lain dari pada berusaha tani, dan bahkan tidak sedikit pula dari generasi millennial ini yang keluar daerah atau merantau. Ini semua menggambarkan bahwa generasi millennial kurang meminati usaha tani. Disisi lain generasi millennial suka tidak suka harus mengambil peran. Generasi millennial saat ini lambat laun menjadi penentu masa depan bagi generasi selanjutnya.

Masyarakat di Desa Lapodi Kecamatan Pasarwajo Kabupaten Buton hingga kini masih banyak yang mengklaim diri sebagai petani. Lokasi pertaniannya juga di klaim memungkinkan untuk melakukan aktifitas pertanian. Sayangnya kenyataan yang tampak oleh mata penulis, usaha tani semakin hari semakin berkurang. Berdasarkan data profil Desa 
Lapodi, penduduk Desa Lapodi tahun 2020 telah mencapai 3336 jiwa, dengan jumlah masyarakat produktif khususnya kaum millennial yang berjumlah 788 jiwa, namun dari jumlah tersebut generasi milenial yang bekerja sebagai petani aktif maupun petani sambilan hanya berjumlah 44 orang .

Lebih lanjut menurut Sitty Muawiyah Panurat (2014) menunjukan bahwa "faktor-faktor yang me-sugesti minat petani seperti luas lahan, pengalaman, pendapatan, bantuan, dan pendidikan. Luas lahan dan pendapatan berpengaruh sangat konkret terhadap minat petani. Sedangkan bantuan dan pengalaman berpengaruh nyata terhadap minat. Sebaliknya pendidikan berpengaruh tidak konkret terhadap minat. Dengan demikian nilai kontribusi Determinan R@ faktor yang mempengaruhi merupakan luas lahan, pengalaman, pendapatan, bantuan dan pendidikan sebanyak 72\%".

Penelitian yang dilakukan oleh Ani Dwi Wimatsari, Sunarru Samsi Hariadi dan Edi Martono (2019) menunjukkan bahwa " faktor-faktor yang mempengaruhi sikap pemuda desa terhadap minat bisnis salak organik yaitu peran orang tua, kiprah penyuluh pertanian lapangan, kiprah media baru, dan persepsi pemuda desa terhadap usaha tani salak organik. Persepsi pemuda desa terhadap bisnis salak organik dan peran orang tua memiliki pengaruh yang positif terhadap pembentukan perilaku pemuda desa, sedangkan peran penyuluh pertanian dan kiprah media baru berpengaruh negatif dalam membangun perilaku pemuda desa terhadap usaha tani salak organik. Kesimpulannya, perilaku pemuda desa berpengaruh positif signifikan terhadap usaha tani salak organik dengan pembentukan minat pemuda desa untuk meneruskan usaha tani salak organik".

Berdasarkan latar belakang yang telah diuraikan di atas maka rumusan masalah pada penelitian ini yaitu "bagaimana pengaruh sikap generasi millennial terhadap minat usaha tani di Desa Lapodi?"

Tujuan yang ingin dicapai dalam penelitian ini adalah untuk mengetahui pengaruh sikap generasi millennial terhadap minat usaha tani di Desa Lapodi.

\section{METODE PENELITIAN}

Penelitian ini dilaksanakan pada Bulan Februari sampai dengan Bulan Maret 2020 di Desa Lapodi Kecamatan Pasarwajo Kabupaten Buton. Populasi pada penelitian ini adalah masyarakat di desa Lapodi yang berusia 20-40 tahun dengan jumlah 44 orang yang merupakan petani millennial. Sampel penelitian merupakan keseluruhan populasi yang diambil menjadi sumber data serta mewakili seluruh populasi. Menurut Arikunto (2010:112) bahwa bila subyeknya holistik dari populasi sebagai akibatnya pengambilan sampel dilakukan secara sensus. Sampel dalam penelitian ini sebanyak 20 orang.

Variabel yang diamati dalam penelitian ini adalah:

1. Variabel dependent (Y), yaitu minat diukur dari:

a. Kesukaan: untuk melihat apakah responden menyukai atau tidak adanya kejenuhan terhadap usaha tani, diukur menggunakan skala likert, dengan skor dari 1- 5, sebagai berikut: Sangat Suka (5) Suka (4) Netral (3) Tidak Suka (2) Sangat Tidak Suka (1).

b. Kemauan: melihat apakah responden lebih tertarik untuk bekerja di pertanian atau di non pertanian, diukur menggunakan skala likert dengan skor dari 1- 5 sebagai berikut: Sangat Mau (5) Mau (4) Netral (3) Tidak Mau (2) Sangat Tidak Mau (1). 


\section{Media Agribisnis}

Vol. 4, Issue 2, November 2020

\section{P-ISSN: 2527-8479 E-ISSN: 2686-2174}

c. Kesenangan: untuk mengetahui apakah responden senang melakukan usaha tani, maka diukur menggunakan skala likert dengan skor dari 1-5, dengan skor yaitu: Sangat Senang (5) Senang (4) Netral (3) Tidak Senang (2) Sangat Tidak Senang (1)

d. Kepuasan: agar usaha tani dapat memberikan kepuasan terhadap responden, maka kepuasan diukur menggunakan skala likert dengan nilai skor dari 1-5 yaitu: sangat puas (5) puas (4) netral (3) tidak puas (2) sangat tidak puas (1).

e. Semangat: Semangat responden terhadap usaha tani diukur menggunakan skala likert dengan skor dari 1- 5, penilaian skor adalah: Sangat Semangat (5) Semangat (4) Netral (3) Tidak Semangat (2) Sangat Tidak Semangat (1).

2. Variabel Bebas (X) terdiri dari beberapa indikator yaitu:
a. Pengalaman.
b. Pendapatan
c. Bantuan.
d. Pendidikan

Berikut disajikan tabel skala likert dan bobot nilai responden

Tabel 1. Skala Likert Dan Bobot Nilai Jawaban Responden

\begin{tabular}{lc}
\hline \multicolumn{1}{c}{ Alternatif jawaban } & Nilai bobot (skor) \\
\hline Sangat suka & 5 \\
\hline suka & 4 \\
\hline Netral & 3 \\
\hline Tidak suka & 2 \\
\hline Sangat tidak suka & 1 \\
\hline
\end{tabular}

Penentuan kelas tersebut di atas akan diperoleh kelas rata-rata nilai indikator sebagai berikut: Skor kriterium $=$ nilai skala $\mathrm{x}$ jumlah responden .

Adapun teknis analisis data pada penelitian ini adalah menggunakan analisis regresi linear berganda, dengan bantuan aplikasi SPSS 16.0. Regresi Linear Berganda adalah model regresi linear dengan melibatkan lebih dari satu variabel bebas atau predictor. (J.T, Mc Clave Bendon P.George, Sincich Terry.2010). Analisis ini untuk mengetahui arah hubungan antara variabel independen dengan variabel dependen apakah positif atau negatif dan untuk memprediksi nilai dari variabel dependen apabila nilai variabel independen mengalami kenaikan atau penurunan. Adapun rumus regresi linear berganda adalah sebagai berikut:

$\mathrm{Y}=\mathrm{a}+\mathrm{bX}$

Keterangan:

$\mathrm{Y}=$ Variabel dependen (nilai yang diprediksikan)

$\mathrm{X}=$ Variabel independen

$\mathrm{a}=$ Konstanta (nilai $\mathrm{Y}$ apabila $\mathrm{X}=0$ )

$\mathrm{b}=$ Koefisien regresi (nilai peningkatan ataupun penurunan)

Kegiatan analisis data adalah mengelompokkan data berdasarkan variabel dan jenis responden, mentabulasi data berdasarkan variabel dari seluruh responden, menyajikan data tiap variabel yang diteliti, melakukan perhitungan untuk menjawab rumusan masalah, dan melakukan perhitungan untuk menguji hipotesis yang telah diajukan”. (Sugiyono.2010: 207) 


\section{Media Agribisnis}

Vol. 4, Issue 2, November 2020

\section{P-ISSN: 2527-8479 E-ISSN: 2686-2174}

Analisis yang digunakan dalam penelitian ini sebagai berikut:

1. Uji Instrumen Penelitian

Penelitian ini menggunakan data primer. Data yang dikumpulkan dengan teknik kuesioner. Kriteria Penelitian yang menggunakan kuesioner sebagai skala pengukuran salah satunya memenuhi kesahihan (validitas) dan kehandalan (reliabilitas).

a. Validitas

"Validitas menunjukkan kinerja kuesioner dalam mengukur apa yang diukur. Tinggi rendahnya validitas instrumen menunjukkan ketepatan data yang terkumpul tidak menyimpang dari data yang sesungguhnya". (Suharsimi Arikunto, Prosedur Penelitian Suatu Pendekatan Praktik... hal. 168).

"Pengujian validitas bertujuan untuk memastikan hasil pengukuran sesuai dengan apa yang diukur. (Tedjo N Reksoatmojo, 2009)

Penelitian ini menggunakan uji isi validitas yang berkaitan dengan sejauhmana tingkat kesesuaian soal-soal dengan isi pekerjaan yang akan diukur. Perhitungan validitas dapat menggunakan rumus product moment. Hasil dari perhitungan SPSS 16.0 akan dibandingkan dengan nilai $r$ tabel pada signifikansi 5\%. Rumus pengujian validitas dengan pearson product moment adalah sebagai berikut: (Tulus Winarsunu, 2006: 70)

$$
" \mathrm{r}_{\text {hitung }}=\frac{N\left(\sum X Y\right)-\left(\sum X\right)\left(\sum Y\right)}{\sqrt{\left\{N \cdot \sum X 2-\left(\sum X\right) 2\right\} \cdot\left\{N \cdot \Sigma Y 2-\left(\sum Y\right) 2\right\}}}+\cdots
$$

Keterangan:

$$
\begin{array}{ll}
\text { rhitung } & =\text { koefisien korelasi } \\
\mathrm{N} & =\text { jumlah responden } \\
\mathrm{X} & =\text { jumlah skor item } \\
\mathrm{Y} & =\text { jumlah skor total } \\
\mathrm{X}^{2} & =\text { jumlah kuadrat skor item } \\
\mathrm{Y}^{2} & =\text { jumlah kuadrat skor total } \\
\mathrm{XY} & =\text { jumlah perkalian skor item dan skor total }
\end{array}
$$

Hasil perhitungan dibandingkan pada tabel kritis $r$ corelasi product moment dengan taraf signifikan 5\%. Jika $r$ maka item tersebut valid dan $r$ tidak valid".

b. Uji Reliabilitas

1. "Membandingkan nilai square root of average variance axtractetd (JAVE) setiap konstruk dengan korelasi antara konstruk dengan konstruk lainnya dalam model. Jika nilai akar AVE setiap konstruk lebih besar dari pada nilai korelasi antara konstruk dengan konstruk lainnya maka dikatakan memiliki nilai discriminant validity yang baik" (Agus Widarjono.2010)

2. "Pengukuran reliabilitas dapat dilakukan dengan melihat nilai Composite Reliability. Jika nilai Composite Reliability antara konstruk dengan indikatorindikatornya memberikan hasil yang baik yaitu di atas 0,70 . Menurut Chin dalam Ghozaly (2006) bahwa jika nilai Composite Reliability 0,70 keatas adalah reliabel dan dapat digunakan untuk penelitian". 


\section{P-ISSN: 2527-8479 E-ISSN: 2686-2174}

\section{Uji Homogenitas}

"Uji homogenitas bertujuan untuk mengetahui apakah kedua kelompok mempunyai varian yang sama atau tidak. Jika kedua kelompok mempunyai varians yang sama maka kelompok tersebut dikatakan homogeny".(Agus Widarjono.2010)

Adapun Membuat hipotesis

a. Menghitung $\mathrm{F}$ dengan rumus.

b. Langkah-langkah uji homogenitas.

- Menentukan $\mathrm{F}_{\text {tabel }}$ dengan taraf signifikansi 5\% dan $d k=n-1$

- Menentukan kriteria pengujian

- Jika $F_{\text {hitung }} \leq F_{\text {tabel }}$ berarti homogen

Jika $F_{\text {hitung }} \geq F_{\text {tabel }}$ berarti tidak homogeny

3. Uji Hipotesis

"Uji t digunakan untuk membuktikan hipotesis ada tidaknya pengaruh masing-masing variabel eksogen secara individu terhadap variabel endogen (Agus Widarjono.2010), dengan langkah-langkah sebagai berikut :

1. Menetapkan hipotesis penelitian

2. Menetapkan standar pengujian dengan syarat taraf signifikan (a) adalah 0,05 dan $t_{\text {table }}$ dengan derajat kebebasan $(\mathrm{df})=\mathrm{n}-\mathrm{k}-1$, dimana $\mathrm{n}=\mathrm{jumlah}$ sampel dan $\mathrm{k}=\mathrm{jumlah}$ variabel eksogen.

3. Hasil pengujian, pengujian hipotesis dalam penelitian ini adalah membandingkan anatara nilai $\mathrm{t}_{\text {table }}$ atau nilai signifikansi $(5 \%$ atau 0,05$)$ dengan penelitian sebagai berikut :

$>$ Jika $t_{\text {hitung }} \geq t_{\text {table }}$ maka Ho ditolak dan Ha diterima dengan hasil penelitian bahwa ada pengaruh signifikan antara variabel satu terhadap variabel lain

$>$ Jika $t_{\text {hitung }}<t_{\text {tabel }}$ maka Ho diterima dan Ha ditolak dengan hasil penelitian adalah tidak ada pengaruh antara satu variabel dengan variabel yang lain.

$>$ Jika nilai signifikansi $\alpha<0,05$ maka Ho ditolak dan Ha diterima artinya terdapat pengaruh yang signifikan antara satu variabel independen terhadap variabel dependen, namun jika $\alpha>0,05$ maka Ho diterima dan Ha ditolak artinya tidak ada pengaruh yang signifikan antara variabel satu variabel independen terhadap variabel dependen".

\section{HASIL DAN PEMBAHASAN}

\section{Deskripsi Responden}

\section{a. Responden berdasarkan Jenis Kelamin}

Pengelompokan responden berdasarkan jenis kelamin pada penelitian ini adalah sebagai berikut :

Tabel 2. Data Responden berdasarkan Jenis Kelamin

\begin{tabular}{cccc}
\hline No & Jenis Kelamin & Jumlah Responden & Persentase (\%) \\
\hline 1. & Laki-laki & 25 & 56,82 \\
\hline
\end{tabular}




\section{P-ISSN: 2527-8479 E-ISSN: 2686-2174}

\begin{tabular}{cccc}
\hline 2. & Perempuan & 19 & 43,18 \\
\hline & Jumlah & $\mathbf{4 4}$ & $\mathbf{1 0 0}$ \\
\hline
\end{tabular}

Sumber : Data Primer yang diolah, 2020

Berdasarkan Tabel 2 dapat dilihat bahwa jumlah responden laki-laki sebesar 56,82\% (25 responden), sedangkan perempuan sebesar 43,18\% (19 responden). Dari data tersebut menunjukkan bahwa generasi millennial yang menjadi responden dalam penelitian ini didominasi oleh laki-laki.

\section{b Resonden Menurut Pendidikan} berikut:

Pengelompokkan responden menurut pendidikan pada penelitian ini adalah sebagai

Tabel 3. Responden Menurut Pendidikan

\begin{tabular}{clcc}
\hline No & Pendidikan & Jumlah Responden & Persentase (\%) \\
\hline 1 & D3/S1 & 8 & 18,18 \\
2 & SMA/Sederajat & 30 & 68,18 \\
3 & SMP/Sederajat & 4 & 9,09 \\
4 & Tidak Sekolah & 2 & 4,55 \\
\hline & Jumlah & $\mathbf{4 4}$ & $\mathbf{1 0 0}$ \\
\hline
\end{tabular}

Sumber: Data Primer yang diolah, 2020

Tabel 3 menunjukkan jumlah responden dengan pendidikan D3/S1 sebanyak 8 Orang $(18,18 \%)$, pendidikan SMA/Sederajat sebanyak 30 Orang $(68,18 \%)$, pendidikan SMP/Sederajat sebanyak 4 Orang $(9,09 \%)$ dan responden yang tidak sekolah/tidak pernah sekolah sebanyak 2 orang (4,55\%). Dari hasil tersebut menunjukkan bahwa responden dalam penelitian ini rata-rata memiliki pendidikan yang memadai umtuk dapat memahami dalam memberikan tanggapan atas angket yang diedarkan.

\section{Deskripsi Variabel}

Penelitian Persepsi responden terhadap variabel yang diteliti menggunakan kriteria rentang sebesar 5-1/3 = 1,33 (Ghozali 2006). Interprestasi rentang nilai adalah sebagai berikut:

$$
\begin{aligned}
& 1,00-2,33=\text { Rendah } \\
& 2,34-3,66=\text { Sedang } \\
& 3,67-5,00=\text { Tinggi }
\end{aligned}
$$

a. Variabel Sikap

Indikator variable sikap mencakup pengalaman, pendapatan, bantuan, dan pendididkan. Berdasarkan penelitian dilapangan indeks indikator pengalaman Nampak pada table 4.

1. Pengalaman 


\section{P-ISSN: 2527-8479 E-ISSN: 2686-2174}

Tabel 4. Pengalaman

\begin{tabular}{clcc}
\hline No & \multicolumn{1}{c}{ Indikator } & $\begin{array}{c}\text { Rata-rata } \\
\text { Jawaban } \\
\text { Responden }\end{array}$ & Kriteria \\
\hline 1. & $\begin{array}{l}\text { Pengalaman usaha tani sudah } \\
\text { lebih dari 5 tahun }\end{array}$ & 3,18 & Sedang \\
2. & $\begin{array}{l}\text { kesulitan dan kemudahan } \\
\text { melakukan usaha tani }\end{array}$ & 3,77 & Tinggi \\
\hline & Jumlah Rata-rata & 3,48 & Sedang \\
\hline
\end{tabular}

Sumber: Data Primer yang diolah, 2020

Tabel 4 di atas menunjukkan bahwa jumlah rata-rata jawaban responden sebesar 3,48. Artinya rata-rata jawaban responden atas indikator pengalaman dengan sub indikator pengalaman kerja lebih dari 5 tahun sebesar 3,18 dan indikator pengalaman dengan sub indikator kemudahan melakukan usaha pertanian sebesar 3,77. Hal ini menujukan bahwa tanggapan responden terhadap pertanyaan mengenai pengalaman di bidang pertanian rata-rata berada pada angka 3,48 dengan kategori sedang, artinya bahwa responden yang menjawab pertanyaan peneliti sudah memiliki pengalaman namun sebagian juga belum sehingga kategori jawaban responden masih pada level sedang. Dengan demikian responden dalam indikator pengalaman dalam variabel sikap sudah sesuai dengan keinginan peneliti sebagai generasi millennial yang masih kurang pengalaman di bidang pertanian karena mereka belum memahami secara baik bagaimana tata cara bertani yang baik. Hasil temuan di lapangan, dapat disajikan pada tabel 5 berikut:

Tabel 5. Tanggapan Responden Terhadap Variabel Sikap Pada Indikator Pengalaman

\begin{tabular}{|c|c|c|c|c|c|c|c|c|c|c|c|c|}
\hline \multirow{2}{*}{$\begin{array}{c}\text { Indikator } \\
\text { Pengalaman }\end{array}$} & \multicolumn{2}{|c|}{ STS } & \multicolumn{2}{|c|}{$\mathrm{TS}$} & \multicolumn{2}{|c|}{$\mathrm{N}$} & \multicolumn{2}{|c|}{ S } & \multicolumn{2}{|c|}{ SS } & \multicolumn{2}{|c|}{ TOTAL } \\
\hline & Jml & $\%$ & $\mathrm{Jml}$ & $\%$ & Jml & $\%$ & $\mathrm{Jml}$ & $\%$ & Jml & $\%$ & $\mathrm{Jml}$ & $\%$ \\
\hline $\begin{array}{l}\text { Pengalaman } \\
\text { usaha tani } \\
\text { sudah lebih } \\
\text { dari } 5 \text { tahun }\end{array}$ & 1 & 2,3 & 16 & 36,4 & 6 & 13,6 & 16 & 36,4 & 5 & 11,4 & 44 & 100 \\
\hline $\begin{array}{l}\text { kesulitan dan } \\
\text { kemudahan } \\
\text { melakukan } \\
\text { usaha tani }\end{array}$ & 0 & 0 & 3 & 6,8 & 10 & 22,7 & 25 & 56,8 & 6 & 13,6 & 44 & 100 \\
\hline
\end{tabular}

Sumber : Data Primer yang diolah, 2020

\section{Keterangan :}

$\begin{array}{ll}\text { STS } & =\text { Sangat Tidak Setuju } \\ \text { TS } & =\text { Tidak Setuju } \\ \mathrm{N} & =\text { Netral } \\ \text { S } & =\text { Setuju } \\ \text { SS } & =\text { Sangat Setuju }\end{array}$


Tabel 5 memperlihatkan bahwa sikap yang dipersepsikan responden pada indikator pengalaman dengan sub indikator pengalaman lebih dari 5 tahun yang menyatakan sangat tidak setuju sebesar 2,3\% (1 responden ), tidak setuju sebesar 36,4\% (16 responden), netral sebanyak $13,6 \%$ (6 responden), setuju sebesar 36,4\% (16 responden) dan sangat setuju sebesar $11,4 \%$ ( 5 responden). Hal tersebut menunjukan bahwa dari hasil penelitian dinyatakan bahwa $47.8 \%$ responden yang mempunyai persepsi baik terhadap pengalaman kerja di atas 5 tahun sedangkan 38,7\% responden tidak memiliki pengalaman pertanian di atas 5 tahun sedangkan selebihnya itu menjawab netral sebesar 13,6\% tidak bersikap atau lebih memilih netral artinya pengalam kerja sebagai petani tidak menentukan sikap seseorang dalam hal melakukan pekerjaannya, dengan artian bahwa lamanya bertani bukan menjadi alasan bahwa petani adalah pekerjaan yang cocok atau sesuai namun para petani millennial memiliki sikap yang tidak peduli dengan pertanian.

Berdasarkan sub indikator kesulitan dan kemudahan melakukan usaha tani, hasil jawaban responden manyatakan bahwa responden yang menjawab sangat tidak setuju sebanyak 0 responden $(0 \%)$ artinya bahwa kaum millennial menjawab pertanyaan pada penelitian ini jawaban sangat tidak setuju adalah tidak ada, selanjutnya jawaban tidak setuju sebanyak 3 orang $(6,8 \%)$, jawaban netral 10 orang $(22,7 \%)$, jawaban setuju sebanyak 25 orang $(56,8 \%)$ dan jawaban sangat setuju 6 orang $(13,6 \%)$. Hal ini menunjukan bahwa pada indikator pengalaman dengan sub indikator kesulitan dan kemudahan mendapat respon positif yaitu di atas $50 \%$, responden menjawab bahwa usaha pertanian memiliki kesulitan maupun kemudahan dalam menjalankannya.

2. Pendapatan

Tabel 6. Pendapatan

\begin{tabular}{|c|c|c|c|}
\hline No & Indikator & $\begin{array}{c}\text { Rata-rata } \\
\text { Jawaban } \\
\text { Responden }\end{array}$ & Kriteria \\
\hline 1. & $\begin{array}{l}\text { Jumlah pendapatan usaha tani } \\
\text { lebih banyak dibandingkan dengan } \\
\text { pendapatan dari usaha lainnya }\end{array}$ & 2,68 & Sedang \\
\hline 2. & $\begin{array}{l}\text { Pendapatan dari hasil usaha tani } \\
\text { yang saya lakukan sudah } \\
\text { memuaskan }\end{array}$ & 2,97 & Sedang \\
\hline 3. & $\begin{array}{l}\text { Pendapatan dari hasil usaha tani } \\
\text { yang saya lakukan mencapai } 2 \text { juta } \\
\text { ke atas perbulan }\end{array}$ & 2,43 & Sedang \\
\hline & Jumlah Rata-rata & 2,69 & Sedang \\
\hline
\end{tabular}

Tabel 6 menunjukan bahwa jumlah rata-rata jawaban responden untuk indikator pendapatan sebanyak 2,69. Dimana jawaban responden rata-rata indikator pendapatan dengan sub indikator jumlah pendapatan sebesar 2,68 dan indikator pendapatan dengan sub indikator pendapatan hasil usaha tani sudah memuaskan sebesar 2,97 dan indikator pendapatan dengan sub indikator pendapatan hasil usaha tani mencapai 2 (dua) juta sebesar 2,43. Hal ini 
menujukan bahwa tanggapan responden terhadap pertanyaan mengenai pendapatan dibidang pertanian rata-rata berada pada angka 2,69 dengan kategori sedang, artinya bahwa responden yang menjawab pertanyaan peneliti sudah memiliki pendapatan dibidang pertanian namun sebagian juga belum sehingga kategori jawaban responden masih pada level sedang. Dengan demikian responden dalam indikator pendapatan dalam variabel sikap sudah sesuai dengan keinginan peneliti sebagai generasi millennial yang masih kurang pendapatannya karena mereka belum memahami secara baik bagaimana tata cara bertani yang baik. Hasil temuan di lapangan, dapat disajikan pada Tabel 7 berikut:

Tabel 7. Tanggapan Responden Terhadap Variabel Sikap Pada Indikator Pendapatan

\begin{tabular}{|c|c|c|c|c|c|c|c|c|c|c|c|c|}
\hline \multirow{2}{*}{$\begin{array}{c}\text { Indikator } \\
\text { Pengalaman }\end{array}$} & \multicolumn{2}{|c|}{ STS } & \multicolumn{2}{|c|}{ TS } & \multicolumn{2}{|c|}{$\mathrm{N}$} & \multicolumn{2}{|c|}{ S } & \multicolumn{2}{|c|}{ SS } & \multicolumn{2}{|c|}{ TOTAL } \\
\hline & Jml & $\%$ & $\mathrm{Jml}$ & $\%$ & Jml & $\%$ & Jml & $\%$ & $\mathrm{Jml}$ & $\%$ & $\mathrm{Jml}$ & $\%$ \\
\hline $\begin{array}{l}\text { Jumlah } \\
\text { Pendapatan } \\
\text { Petani }\end{array}$ & 5 & 11,4 & 8 & 18,2 & 28 & 63,6 & 2 & 4,5 & 1 & 2,3 & 44 & 100 \\
\hline $\begin{array}{lr}\text { Hasil } & \text { Usaha } \\
\text { Tani } & \text { Yang } \\
\text { Memuaskan }\end{array}$ & 2 & 4,5 & 12 & 27,3 & 17 & 38,6 & 11 & 25,0 & 2 & 4,5 & 44 & 100 \\
\hline $\begin{array}{l}\text { Hasil usaha di } \\
\text { atas } \\
\text { Juta/Bulan }\end{array}$ & 8 & 18,2 & 16 & 36,4 & 13 & 29,5 & 7 & 15,9 & 0 & 0 & 44 & 100 \\
\hline
\end{tabular}

Sumber : Data Primer yang diolah, 2020

Tabel 7 menunjukan bahwa sikap yang dipersepsikan responden pada indikator pendapatan dengan sub jumlah pendapatan petani sebanyak 5 responden $(11,4 \%)$ menyatakan sangat tidak setuju, 8 responden $(18,2 \%)$ menjawab tidak setuju, 28 responden $(63,6 \%)$ menjawab netral, sebanyak 2 responden $(4,5 \%)$ menjawab setuju dan 1 responden $(2,3 \%)$ menjawab sangat setuju. Hal ini menunjukan bahwa dari hasil penelitian dinyatakan bahwa sebagian besar responden menyatakan bahwa usaha pertanian tidak dapat meningkatkan pendapatan petani karena sebesar 29,6\% responden menjawab sangat tidak setuju dan tidak setuju apabila diberi pertanyaan bahwa usaha pertanian dapat meningkatkan pendapatan para petani, sedangkan yang sepakat atau setuju dan sangat setuju dari pertanyaan bahwa usaha pertanian dapat meningkatkan pandapatan petani hanya $8,8 \%$, artinya masyarakat milenial atau generasi milenial yang setuju bahwa petani dapat meningkatkan pendapatan petani hanya $8,8 \%$ sedangkan $91,2 \%$ generasi milenial tidak setuju bahwa usaha pertanian dapat meningkatkan pendapatannya.

Sub indikator hasil usaha pertanian memuaskan. Berdasarkan hasil jawaban responden pada sub indikator tersebut manyatakan bahwa responden yang menjawab sangat tidak setuju sebanyak 2 responden (4,5\%), selanjutnya responden yang menjawab tidak setuju sebanyak 12 responden $(27,3 \%)$, netral sebanyak 17 responden $(38,6 \%)$, setuju sebanyak 11 responden (25\%) dan sangat setuju 2 responden $(4,5 \%)$. Hal ini menunjukan bahwa pada indikator pengalaman dengan sub indikator usaha pertanian memuaskan mendapat respon yang kurang baik yaitu hanya $29,5 \%$, responden menjawab bahwa usaha pertanian memuaskan, sedangkan $31,8 \%$ responden menjawab bahwa hasil pertanian tidak memuaskan selebihnya itu atau sebesar 38,6 responden menjawab netral. Dengan demikian pada hasil kuesioner generasi milenial tidak mau bertani karena hasil yang kurang memuaskan sehingga generasi milenial 
yang bertani hanya sebagai pekerjaan sampingan sambil mencari pekerjaan lain yang lebih menjamin kehidupan, gambaran demikian dapat dilihat dari tingginya angka netral pada pertanyaan ini bahkan bila yang menjawab netral ditambhkan dengan responden yang menjawab tidak setuju maka lebih dari $50 \%$ generasi milenial tidak setuju bertani karena hasil yang tidak memuaskan.

Sub indikator hasil usaha di atas 2 juta/bulan. Berdasarkan hasil jawaban responden pada sub indikator tersebut manyatakan bahwa responden yang menjawab sangat tidak setuju sebanyak 8 responden $(18,2 \%)$, selanjutnya responden yang menjawab tidak setuju sebanyak 16 responden $(36,4 \%)$, netral sebanyak 13 responden $(29,5 \%)$, setuju sebanyak 7 responden $(15,9 \%)$ dan sangat setuju 0 responden $(0 \%)$. Dari gambaran di atas dapat dihasilkan bahwa hasil usaha pertanian berada di bawah 2 juta atau di bawah Upah Minimum Regional (UMR)/Bulan, hal ini dapat dilihat dari jawaban responden yang menyatakan setuju bahwa pendapatan perbulan di atas 2 juta hanya $15,9 \%$ sedangkan $54,6 \%$ atau di atas $50 \%$ petani millennial menyatakan bahwa pendapatan petani sangat memprihatinkan karena berada di bawah 2 juta. Oleh karena itu banyak generasi millennial yang tidak mau menjadi petani karena segi pendapatan tidak dapat mencukupi kebutuhan hidup masyarakat.

3. Bantuan

Tabel 8. Bantuan

\begin{tabular}{llcc}
\hline No & \multicolumn{1}{c}{ Indikator } & $\begin{array}{c}\text { Rata-rata Jawaban } \\
\text { Responden }\end{array}$ & Kriteria \\
\hline & $\begin{array}{l}\text { Usaha tani yang saya } \\
\text { lakukan mendapat bantuan } \\
\text { dari pemerintah, perbankan, } \\
\text { maupun koperasi. }\end{array}$ & 2,13 & Rendah \\
& & & \\
2. & $\begin{array}{l}\text { Bantuan dana yang saya } \\
\text { peroleh semua digunakan } \\
\text { untuk kegiatan usaha tani }\end{array}$ & 2,54 & Sedang \\
\hline
\end{tabular}

Sumber : Data Primer yang diolah, 2020

Tabel 8 menunjukan bahwa jumlah rata-rata jawaban responden atas indikator bantuan sebesar 2,34. Rata-rata Jawaban responden atas indikator Bantuan dengan sub indikator usaha tani yang saya lakukan mendapat bantuan dari pemerintah, perbankan maupun koperasi sebesar 2,13 dan indikator bantuan dana yang saya peroleh semua digunakan untuk kegiatan usaha tani sebesar 2,54. Hal ini menujukan bahwa tanggapan responden terhadap pertanyaan bantuan rata-rata berada pada angka 2,34 dengan kategori sedang, artinya bahwa responden yang menjawab pertanyaa Usaha tani yang saya lakukan mendapat bantuan dari pemerintah, perbankan, maupun koperasi berada pada ketegori rendah artinya bahwa sebagian besar kegiatan pertanian di Desa Lapodi bersumber dari dana pribadi, sedangkan pada sub indikator bantuan dana yang saya peroleh semua digunakan untuk kegiatan usaha tani rata-rata jawaban responden berada pada kategori sedang artinya bahwa masyarakat petani Desa Lapodi menyatakan bahwa bila terdapat bantuan usaha pertanian dari pemerintah maka sebagian besar anggaranya digunakan untuk usaha pertanain. Hasil temuan di lapangan, dapat disajikan pada tabel 9 berikut : 


\section{P-ISSN: 2527-8479 E-ISSN: 2686-2174}

Tabel 9. Tanggapan Responden Terhadap Variabel Sikap Pada Indikator Bantuan

\begin{tabular}{|c|c|c|c|c|c|c|c|c|c|c|c|c|}
\hline \multirow{2}{*}{$\begin{array}{c}\text { Indikator } \\
\text { Pengalaman }\end{array}$} & \multicolumn{2}{|c|}{ STS } & \multicolumn{2}{|c|}{$\mathrm{TS}$} & \multicolumn{2}{|c|}{$\mathrm{N}$} & \multicolumn{2}{|c|}{$\mathrm{S}$} & \multicolumn{2}{|c|}{ SS } & \multicolumn{2}{|c|}{ TOTAL } \\
\hline & $\mathrm{Jml}$ & $\%$ & $\mathrm{Jml}$ & $\%$ & $\mathrm{Jml}$ & $\%$ & $\mathrm{Jml}$ & $\%$ & $\mathrm{Jml}$ & $\%$ & $\mathrm{Jml}$ & $\%$ \\
\hline $\begin{array}{l}\text { Usaha tani } \\
\text { yang saya } \\
\text { lakukan } \\
\text { mendapat } \\
\text { bantuan dari } \\
\text { pemerintah, } \\
\text { perbankan, } \\
\text { maupun } \\
\text { koperasi. }\end{array}$ & 15 & 34,1 & 13 & 29,5 & 11 & 25,0 & 5 & 11,4 & 0 & 0 & 44 & 100 \\
\hline $\begin{array}{l}\text { Bantuan dana } \\
\text { yang saya } \\
\text { peroleh semua } \\
\text { digunakan } \\
\text { untuk } \\
\text { kegiatan } \\
\text { usaha tani }\end{array}$ & 9 & 20,5 & 12 & 27,3 & 14 & 31,8 & 8 & 18,2 & 1 & 2,3 & 44 & 100 \\
\hline
\end{tabular}

Sumber: Data Primer yang diolah, 2020

Berdasarkan tabel 9 dapat dilihat bahwa sikap yang dipersepsikan responden pada indikator bantuan dengan sub indikator Usaha tani yang saya lakukan mendapat bantuan dari pemerintah, perbankan, maupun koperasi memperoleh jawaban sangat tidak setuju sebesar $34,1 \%$ (15 responden), jawaban tidak setuju sebesar 29,5\% (13 responden), jawaban netral sebesar $25,0 \%$ (11 responden), jawaban setuju sebesar 11,4\% (5 responden) dan jawaban sangat setuju sebesar $(0 \%)$. Hal tersebut menunjukan bahwa dari hasil penelitian dinyatakan bahwa sebagian besar responden menyatakan bahwa usaha pertanian yang mereka lakukan mendapatkan bantuan dari pemerintah, perbankan ataupun koperasi sebagian besar menyatakan tidak sepakat atau sebesar 28 responden $(63,6 \%)$, hal ini menujukkan bahwa petani millennial di Desa Lapodi hanya sebagian kecil saja yang mendapatkan bantuan dari pemerintah atau perbankan, sebagian besar petani melakukan usaha pertanian karena berasal dari usaha sendiri atau modal sendiri. Sedangkan yang setuju bahwa masyarakat melakukan pertanian karena mendapatkan bantuan dari pemerintah sebesar 11,4 \%. Hal ini menunjukkan bahwa petani yang mendapatkan bantuan dalam bertani sangat kecil dan sebagian besar menggunakan dana pribadi untuk bertani.

Pendidikan

Tabel 10. Pendidikan

\begin{tabular}{llcc}
\hline No & \multicolumn{1}{c}{ Indikator } & $\begin{array}{c}\text { Rata-rata Jawaban } \\
\text { Responden }\end{array}$ & Kriteria \\
\hline $1 . \quad \begin{array}{l}\text { Untuk melakukan usaha tani, } \\
\text { saya memerlukan pelatihan } \\
\text { dari penyuluh pertanian }\end{array}$ & 3,95 & Tinggi \\
& $\begin{array}{l}\text { tentang usaha tani. } \\
\text { Saya melakukan usaha tani } \\
\text { karena pengalaman dibidang } \\
\text { usaha tani }\end{array}$ & 3,45 & Sedang \\
& Jumlah Rata-rata & Sedang \\
\hline \multicolumn{3}{l}{ Sumber : Data Primer yang diolah, 2020 }
\end{tabular}




\section{P-ISSN: 2527-8479 E-ISSN: 2686-2174}

Tabel 10 menunjukan bahwa jumlah rata-rata jawaban responden untuk indikator pendidikan sebesar 3,25. Rata-rata jawaban responden untuk indikator pendidikan dengan sub indikator untuk melakukan usaha tani, saya memerlukan pelatihan dari penyuluh pertanian tentang usaha tani sebesar 3,95 dan sub indikator Saya melakukan usaha tani karena pengalaman dibidang usaha tani sebesar 3,45. Hal ini menujukan bahwa tanggapan responden terhadap pertanyaan pendidikan rata-rata berada pada angka 3,25 dengan kategori sedang, artinya bahwa responden yang menjawab pertanyaan untuk melakukan usaha tani, saya memerlukan pelatihan dari penyuluh pertanian tentang usaha tani berada pada ketegori tinggi artinya bahwa sebagian besar petani generasi milenial di Desa Lapodi membutuhkan tenaga penyuluh dalam hal mendidik para petani tentang bagaimana cara bertani yang baik, dengan adanya pemberian penyuluhan kepada para petani maka akan berakibat baik. Sedangkan pada sub indikator Saya melakukan usaha tani karena pengalaman dibidang usaha tani rata-rata jawaban responden berada pada kategori sedang artinya para petani millennial terbagi atas 2 yaitu para petani millennial yang bertani karena tidak ada pekerjaan sedangkan sebagian yang lain bekerja sebagai petani karena memiliki pengalaman dibidang pertanian. Data Jawaban responden untuk Indikator Pendidkan, dapat dilihat pada tabel 11 berikut :

Tabel 11. Tanggapan Responden Terhadap Variabel Sikap Pada Indikator Pendidikan

\begin{tabular}{|c|c|c|c|c|c|c|c|c|c|c|c|c|}
\hline \multirow{2}{*}{$\begin{array}{c}\text { Indikator } \\
\text { Pengalaman }\end{array}$} & \multicolumn{2}{|c|}{ STS } & \multicolumn{2}{|c|}{$\mathrm{TS}$} & \multicolumn{2}{|c|}{$\mathrm{N}$} & \multicolumn{2}{|c|}{$S$} & \multicolumn{2}{|c|}{ SS } & \multicolumn{2}{|c|}{ TOTAL } \\
\hline & Jml & $\%$ & Jml & $\%$ & Jml & $\%$ & Jml & $\%$ & Jml & $\%$ & $\mathrm{Jml}$ & $\%$ \\
\hline $\begin{array}{l}\text { Untuk } \\
\text { melakukan } \\
\text { usaha tani, } \\
\text { saya } \\
\text { memerlukan } \\
\text { pelatihan } \\
\text { dari } \\
\text { penyuluh } \\
\text { pertanian } \\
\text { tentang } \\
\text { usaha tani. }\end{array}$ & 2 & 4,5 & 4 & 9,1 & 3 & 6,8 & 20 & 45,5 & 12 & 34,1 & 44 & 100 \\
\hline Indikator & & & & & & & & & & & & $\overline{\mathrm{AL}}$ \\
\hline Pengalaman & Jml & $\%$ & Jml & $\%$ & $\mathrm{Jml}$ & $\%$ & Jml & $\%$ & Jml & $\%$ & $\mathrm{Jml}$ & $\%$ \\
\hline $\begin{array}{l}\text { Saya } \\
\text { melakukan } \\
\text { usaha tani } \\
\text { karena } \\
\text { pengalaman } \\
\text { dibidang } \\
\text { usaha tani }\end{array}$ & 2 & 4,5 & 6 & 13,6 & 12 & 27,3 & 18 & 40,9 & 6 & 13,6 & 44 & 100 \\
\hline
\end{tabular}

Sumber : Data Primer yang diolah, 2020

Berdasarkan tabel 11 dapat dilihat bahwa jawaban responden pada indikator pendidikan dengan sub indikator pelatihan dari penyuluh pertanian tentang usaha tani memperoleh jawaban sangat tidak setuju sebanyak 2 responden (4,5\%), tidak setuju sebanyak 4 responden $(9,1 \%)$, netral sebanyak 3 responden $(6,8 \%)$, setuju sebanyak 20 responden $(45,5 \%)$ dan sangat setuju sebanyak 12 responden $(34,1 \%)$. Hal tersebut menunjukkan bahwa dari hasil penelitian dinyatakan bahwa sebagian besar responden menyatakan bahwa dalam melakukan 


\section{P-ISSN: 2527-8479 E-ISSN: 2686-2174}

usaha pertanian perlu adanya pelatihan yang dilakukan oleh para penyuluh pertanian sehingga hasilnya dapat memuaskan.

b. Variabel Minat

Tabel 12. Minat

\begin{tabular}{|c|c|c|c|}
\hline No & Indikator & $\begin{array}{l}\text { Rata-rata Jawaban } \\
\text { Responden }\end{array}$ & Kriteria \\
\hline 1. & $\begin{array}{l}\text { Saya senang melakukan usaha tani karena } \\
\text { jumlah pendapatan yang dihasilkan sudah } \\
\text { cukup besar }\end{array}$ & 3,04 & Sedang \\
\hline 2. & $\begin{array}{l}\text { Saya senang melakukan usaha tani karena } \\
\text { dapat menciptakan bahan pokok yang } \\
\text { dibutuhkan oleh manusia }\end{array}$ & 4,11 & Tinggi \\
\hline 3. & $\begin{array}{l}\text { Saya bahagia melakukan usaha tani karena } \\
\text { dapat menciptakan lapangan kerja baru }\end{array}$ & 3,36 & Sedang \\
\hline 4. & $\begin{array}{l}\text { Saya suka melakukan usaha tani kerena } \\
\text { saya sudah berpengalaman melakukan } \\
\text { usaha tani }\end{array}$ & 3,34 & Sedang \\
\hline 5. & $\begin{array}{l}\text { Saya suka melaksanakan usaha tani karena } \\
\text { memiliki kebebasan dari sisi waktu }\end{array}$ & 3,88 & Tinggi \\
\hline 6. & $\begin{array}{l}\text { Saya suka usaha tani karena dapat } \\
\text { membantu dalam perekonomian keluarga }\end{array}$ & 4,32 & Tinggi \\
\hline 7. & $\begin{array}{l}\text { Saya merasa puas atas produksi usaha } \\
\text { yang saya hasilkan. }\end{array}$ & 3,59 & Sedang \\
\hline 8. & $\begin{array}{l}\text { Saya merasa puas, karena dari usaha tani } \\
\text { saya bisa mengenal berbagai jenis } \\
\text { tanaman dengan berbagai karakteristiknya }\end{array}$ & 4,04 & Tinggi \\
\hline 9. & $\begin{array}{l}\text { Semangat saya melakukan usaha tani } \\
\text { tergantung dari kondisi pasar }\end{array}$ & 3,34 & Sedang \\
\hline 10. & $\begin{array}{l}\text { Saya bersemangat melakukan usaha tani } \\
\text { karena bersentuhan langsung dengan alam } \\
\text { sekaligus manusia. }\end{array}$ & 3,97 & Tinggi \\
\hline 11. & $\begin{array}{l}\text { Saya bersemangat melakukan usaha tani } \\
\text { karena dapat menghasilkan modal usaha. }\end{array}$ & 3,63 & Sedang \\
\hline 12. & $\begin{array}{l}\text { Saya mau melakukan usaha tani karena } \\
\text { sudah memiliki lahan untuk membuka } \\
\text { usaha. }\end{array}$ & 3,72 & Tinggi \\
\hline 13. & $\begin{array}{l}\text { Saya mau melakukan usaha tani karena } \\
\text { banyaknya peluang dalam usaha tersebut. }\end{array}$ & 3,54 & Sedang \\
\hline 14. & $\begin{array}{l}\text { Saya mau melakukan usaha tani karena } \\
\text { dukungan dari keluarga. }\end{array}$ & 3.09 & Sedang \\
\hline 15. & $\begin{array}{l}\text { Saya mau melakukan usaha tani karena } \\
\text { memiliki lahan yang memadai }\end{array}$ & 3,70 & Tinggi \\
\hline & Rata-rata Keseluruhan & 3,65 & Sedang \\
\hline
\end{tabular}




\section{Media Agribisnis}

\section{Vol. 4, Issue 2, November 2020}

\section{P-ISSN: 2527-8479 E-ISSN: 2686-2174}

\section{Sumber: Data Primer Yang diolah, 2020}

Tabel 12 menunjukkan bahwa rata-rata keseluruhan jawaban responden sebesar 3,65 dengan kategori sedang. Secara rinci jawaban responden terhadap variabel minat dengan indikator saya senang melakukan usaha tani karena jumlah pendapatan yang dihasilkan sudah cukup besar sebesar 3,04 dengan kategori sedang artinya bahwa sebagian besar responden menyatakan bahwa pendapatan petani terjadi peningkatan. Selanjutnya pada indikator saya senang melakukan usaha tani karena dapat menciptakan bahan pokok yang dibutuhkan oleh manusia sebesar 4,11 dengan kategori tinggi artinya bahwa usaha di bidang pertanian dapat meningkatkan atau menjadi peluang untuk mendapatkan pekerjaan. Selanjutnya pada indikator saya bahagia melakukan usaha tani karena dapat menciptakan lapangan kerja baru sebesar 3,36 dengan kategori sedang artinya bahwa usaha tani dalam pandangan petani millennial dapat menciptakan lapangan kerja. Selanjutnya pada indikator saya suka melakukan usaha tani karena saya sudah berpengalaman melakukan usaha tani sebesar 3,34 dengan kategori sedang artinya bahwa sebagian masyarakat yang melakukan usaha pertanian sudah berpengalaman dan sebagian juga belum berpengalaman. Selanjutnya pada indikator saya suka usaha tani karena dapat membantu dalam perekonomian keluarga sebesar 3,88 dengan kategori tinggi artinya bahwa usaha pertanian dapat membantu perekonomian keluarga, selanjutnya indikator saya merasa puas atas produksi usaha yang saya hasilkan sebesar 4,32 dengan kategori tinggi artinya bahwa kepuasan masyarakat dalam hal melakukan usaha pertanian dapat membantu usaha perekonomian keluarga. Selanjutnya pada indikator saya merasa puas, karena dari usaha tani saya bisa mengenal berbagai jenis tanaman dengan berbagai karakteristiknya sebesar 3,59 dengan kategori sedang artinya bahwa usaha pertanian dapat mengenal berbagai jenis tanaman. Selanjutnya pada indikator semangat saya melakukan usaha tani tergantung dari kondisi pasar sebesar 4,04 dengan kategori tinggi artinya bahwa penghasilan usaha pertanian sangat bergantung pada kondisi pasar, bila kondisi bagus untuk perekonomian maka akan meningkatkan perekonomian para usaha pertanian. Selanjutnya pada indikator saya bersemangat melakukan usaha tani karena bersentuhan langsung dengan alam sekaligus manusia sebesar 3,34 dengan kategori sedang artinya bahwa bekerja sebagai usaha pertanian dapat berhubungan langsung dengan alam sehingga hasil pertanian masyarakat dapat dirasakan langsung oleh para petani itu sendiri. Selanjutnya pada indikator saya bersemangat melakukan usaha tani karena dapat menghasilkan modal usaha sebesar 3,97 dengan kategori tinggi artinya bahwa dengan adanya usaha tani dapat meningkatkan modal usaha. Selanjutnya pada indikator saya mau melakukan usaha tani karena sudah memiliki lahan untuk membuka usaha sebesar 3,63 dengan kategori sedang artinya bahwa para pengusaha yang melakukan usaha tani karena memiliki lahan dan biasanya lahan tidur yang belum ditumbuhi atau belum ditanami oleh tanaman jangka panjang sehingga lahan tersebut digunakan untuk usaha sampingan. Selanjutnya pada indikator saya mau melakukan usaha tani karena banyaknya peluang dalam usaha tersebut sebesar 3,72 dengan kategori tinggi artinya bahwa usaha pertanian masih memiliki peluang karena lahan pertanian masih banyak sehingga masyarakat millennial atau generasi millennial memiliki peluang besar untuk bertani karena di samping luas lahan yang masih banyak juga dari sisi tenaga/fisik masih mampu untuk melakukan usaha pertanian. Selanjutnya indikator Saya mau melakukan usaha tani karena dukungan dari keluarga sebesar 3,54 dengan kategori sedang artinya bahwa usaha di bidang pertanian dari sisi dukungan dari keluarga relatif sedang, dimana keluarga tidak mendukung secara penuh tentang usaha pertanian karena bagi masyarakat pertanian bukan 


\section{Media Agribisnis}

\section{Vol. 4, Issue 2, November 2020}

\section{P-ISSN: 2527-8479 E-ISSN: 2686-2174}

usaha yang menjanjikan, usaha pertanian hanya sebagai sampingan sebelum mendapatkan pekerjaan yang lebih layak lagi. Selanjutnya pada indikator saya mau melakukan usaha tani karena memiliki lahan yang memadai sebesar 3,09 dengan kategori sedang artinya bahwa lahan merupakan salah satu media yang penting untuk melakukan usaha pertanian sehingga lahan menjadi faktor utama dalam generasi millennial melakukan usaha pertanian, namun demikian saat ini lahan pertanian sudah sempit oleh pemukiman masyarakat sehingga generasi millennial sulit untuk mendapatkan lahan sehingga untuk menjadi petani harus meminjam lahan tidur atau peminjam lahan orang lain.

\section{Uji Indikator dan Variabel}

Berdasarkan hasil analisis SPSS dapat dilihat hasil Uji Indikator dan Variabel sebagai berikut.

1. Uji Validitas

Berdasarkan uji SPSS, uji validitas variabel penelitian ini ada pada tabel di bawah ini:

Tabel 13. Hasil Uji Validitas Indikator

\begin{tabular}{cc}
\hline Indikator/ Pertanyaan & Nilai \\
\hline X1.1 & 18.739 \\
\hline X1.2 & 32.353 \\
\hline X2.1 & 21.461 \\
\hline X2.2 & 20.743 \\
\hline X2.3 & 16.561 \\
\hline X3.2 & 13.825 \\
\hline X4.1 & 15.518 \\
\hline X4.2 & 23.875 \\
\hline Y1.1 & 21.939 \\
\hline Y1.2 & 20.969 \\
\hline Y2.1 & 31.420 \\
\hline Y2.2 & 21.530 \\
\hline Y2.3 & 21.453 \\
\hline Y2.4 & 32.881 \\
\hline Y3.1 & 38.709 \\
\hline Y3.2 & 30.264 \\
\hline Y4.1 & Nilai \\
\hline Y4.2 & 28.580 \\
\hline Y4.3 & 21.453 \\
\hline Y5.1 & 31.083 \\
\hline Y5.2 & 27.054 \\
\hline Y5.3 & 28.340 \\
\hline Y5.4 & 28.682 \\
\hline & 19.083 \\
\hline & 27.175 \\
\hline Indikator/ Pertanyaan & \\
\hline
\end{tabular}




\section{Media Agribisnis}

\section{Vol. 4, Issue 2, November 2020}

\section{P-ISSN: 2527-8479 E-ISSN: 2686-2174}

Berdasarkan tabel 13 di atas melalui uji SPSS diketahui bahwa semua indikator pada penelitian ini di atas t-tabel $=1,67$, dengan demikian semua indikator memiliki nilai t-hitung $>$ t-tabel sehingga semua indikator dapat diteliti atau valid.

2. Uji Reliabilitas

Tabel 14. Uji Reliabilitas Variabel

\begin{tabular}{|r|r|}
\hline \multicolumn{2}{|c|}{ Reliability Statistics } \\
\hline Cronbach's Alpha & N of Items \\
\hline & \\
\hline & \\
\hline
\end{tabular}

Berdasarkan uji SPSS diketahui bahwa reliabilitas sebesar 0,884 artinya bahwa sebesar $88,4 \%$ variabel dalam penelitian ini, dimana semua faktor yang variabel dapat saling mempengaruhi antara variabel sikap terhadap minat sebesar $88,4 \%$ sedangkan dipengaruhi oleh faktor lain hanya $11,6 \%$. Dengan demikian pada penelitian ini semua variabel memiliki kategori reliabel atau sesuai dengan keinginan peneliti untuk melakukan penelitian karean standar variabel yang tidak reliabilitas di bawah $70 \%$. Oleh karena itu nilai $88,4 \%>70 \%$ maka penelitian ini memenuhi standar reliability.

3. Uji Normalitas

Gambar 1. Gambar Hasil Print SPSS

Normal P-P Plot of Regression Standardized Residual

Dependent Variable: Sikap

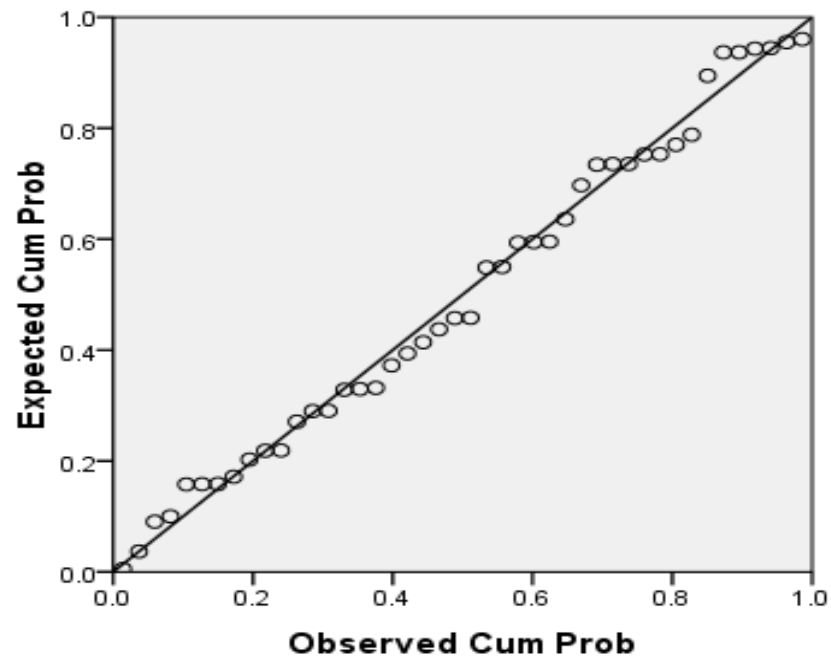




\section{Media Agribisnis}

\section{Vol. 4, Issue 2, November 2020}

\section{P-ISSN: 2527-8479 E-ISSN: 2686-2174}

Berdasarkan gambar 1 di atas dapat diketahui bahwa variabel sikap dan variabel minat yang diteliti memenuhi syarat untuk diteliti karena titik-titik berada pada garis lurus artinya bahwa apabila lingkaran-lingkaran kecil tersebut tersebar dan tidak mengikuti garis lurus maka variabel tidak dapat diteliti atau variabel tersebut tidak reliabel namun titik-titik tersebut masih mengikuti garis lurus berarti variabel yang diteliti oleh peneliti memenuhi syarat untuk dilanjutkan hasil penelitian. Hal tersebut diungkapkan oleh Agus Widarjono (2010) yang menyatakan bahwa pada uji normalitas dapat dilihat dari garis lurus, apabila titik-titik mengikuti garis lurus maka dinyatakan data yang disampaikan normal dan dapat dilanjutkan pada tingkatan hasil penelitian.

Tabel 15. Hasil Uji T-Sample Test

\begin{tabular}{|c|c|c|c|}
\hline \multirow[t]{2}{*}{ Tes One Sample Test } & \multirow[t]{2}{*}{ t-hitung } & \multicolumn{2}{|c|}{$\begin{array}{l}\text { 95\% Confidence Interval of } \\
\text { the Difference }\end{array}$} \\
\hline & & Lower & Upper \\
\hline $\begin{array}{l}\text { Saya melakukan usaha tani sudah } \\
\text { lebih dari } 5 \text { tahun }\end{array}$ & 18.739 & 2.84 & 3.52 \\
\hline $\begin{array}{l}\text { Saya sudah tahu kesulitan dan } \\
\text { kemudahan melakukan usaha tani }\end{array}$ & 32.353 & 3.54 & 4.01 \\
\hline $\begin{array}{l}\text { Jumlah pendapatan usaha tani lebih } \\
\text { banyak dibandingkan dengan } \\
\text { pendapatan dari usaha lainnya }\end{array}$ & 21.461 & 2.43 & 2.93 \\
\hline $\begin{array}{l}\text { Pendapatan dari hasil usaha tani yang } \\
\text { saya lakukan sudah memuaskan }\end{array}$ & 20.743 & 2.69 & 3.27 \\
\hline $\begin{array}{l}\text { Pendapatan dari hasil usaha tani yang } \\
\text { saya lakukan mencapai } 2 \text { juta ke atas } \\
\text { perbulan }\end{array}$ & 16.561 & 2.14 & 2.73 \\
\hline $\begin{array}{l}\text { Usaha tani yang saya lakukan } \\
\text { mendapat bantuan dari pemerintah, } \\
\text { perbankan, maupun koperasi }\end{array}$ & 13.825 & 1.82 & 2.45 \\
\hline $\begin{array}{l}\text { Bantuan dana yang saya peroleh } \\
\text { semua digunakan untuk kegiatan } \\
\text { usaha tani }\end{array}$ & 15.518 & 2.21 & 2.88 \\
\hline $\begin{array}{l}\text { Untuk melakukan usaha tani, saya } \\
\text { memerlukan pelatihan dari penyuluh } \\
\text { pertanian tentang usaha tani }\end{array}$ & 23.875 & 3.62 & 4.29 \\
\hline $\begin{array}{l}\text { Saya melakukan usaha tani karena } \\
\text { pengalaman di bidang usaha tani. }\end{array}$ & 21.939 & 3.14 & 3.77 \\
\hline $\begin{array}{l}\text { Saya senang melakukan usaha tani } \\
\text { karena jumlah pendapatan yang } \\
\text { dihasilkan sudah cukup besar }\end{array}$ & 20.969 & 2.75 & 3.34 \\
\hline $\begin{array}{l}\text { Saya senang melakukan usaha tani } \\
\text { karena dapat menciptakan bahan } \\
\text { pokok yang dibutuhkan oleh manusia }\end{array}$ & 31.420 & 3.85 & 4.38 \\
\hline $\begin{array}{l}\text { Saya bahagia melakukan usaha tani } \\
\text { karena dapat menciptakan lapangan }\end{array}$ & 21.530 & 3.05 & 3.68 \\
\hline
\end{tabular}




\section{Media Agribisnis}

Vol. 4, Issue 2, November 2020

\section{P-ISSN: 2527-8479 E-ISSN: 2686-2174}

\begin{tabular}{|c|c|c|c|}
\hline \multicolumn{4}{|l|}{ kerja baru } \\
\hline $\begin{array}{l}\text { Saya suka melakukan usaha tani } \\
\text { karena saya sudah berpengalaman } \\
\text { melakukan usaha tani }\end{array}$ & 21.453 & 3.03 & 3.65 \\
\hline \multirow[t]{2}{*}{ Tes One Sample Test } & \multirow[t]{2}{*}{ t-hitung } & \multicolumn{2}{|c|}{$\begin{array}{l}\text { 95\% Confidence Interval of } \\
\text { the Difference }\end{array}$} \\
\hline & & Lower & Upper \\
\hline $\begin{array}{l}\text { Saya suka melaksanakan usaha tani } \\
\text { karena memiliki kebebasan dari sisi } \\
\text { waktu }\end{array}$ & 32.881 & 3.65 & 4.12 \\
\hline $\begin{array}{l}\text { Saya suka usaha tani karena dapat } \\
\text { membantu dalam perekonomian } \\
\text { keluarga }\end{array}$ & 38.709 & 4.09 & 4.54 \\
\hline $\begin{array}{l}\text { Saya merasa puas atas produksi } \\
\text { usaha yang saya hasilkan }\end{array}$ & 30.264 & 3.35 & 3.83 \\
\hline $\begin{array}{l}\text { Saya merasa puas, karena dari usaha } \\
\text { tani saya bisa mengenal berbagai } \\
\text { jenis tanaman dengan berbagai } \\
\text { karakteristiknya }\end{array}$ & 28.580 & 3.76 & 4.33 \\
\hline $\begin{array}{l}\text { Semangat saya melakukan usaha tani } \\
\text { tergantung dari kondisi pasar }\end{array}$ & 21.453 & 3.03 & 3.65 \\
\hline $\begin{array}{l}\text { Saya bersemangat melakukan usaha } \\
\text { tani karena bersentuhan langsung } \\
\text { dengan alam sekaligus manusia }\end{array}$ & 31.083 & 3.72 & 4.24 \\
\hline $\begin{array}{l}\text { Saya bersemangat melakukan usaha } \\
\text { tani karena dapat menghasilkan } \\
\text { modal usaha }\end{array}$ & 27.054 & 3.37 & 3.91 \\
\hline $\begin{array}{l}\text { Saya mau melakukan usaha tani } \\
\text { karena sudah memiliki lahan untuk } \\
\text { membuka usaha }\end{array}$ & 28.340 & 3.46 & 3.99 \\
\hline $\begin{array}{l}\text { Saya mau melakukan usaha tani } \\
\text { karena banyaknya peluang dalam } \\
\text { usaha tersebut }\end{array}$ & 28.682 & 3.30 & 3.79 \\
\hline $\begin{array}{l}\text { Saya mau melakukan usaha tani } \\
\text { karena dukungan dari keluarga }\end{array}$ & 19.083 & 2.76 & 3.42 \\
\hline $\begin{array}{l}\text { Saya mau melakukan usaha tani } \\
\text { karena memiliki lahan yang memadai }\end{array}$ & 27.175 & 3.43 & 3.98 \\
\hline
\end{tabular}

Berdasarkan uji SPSS dengan menggunakan uji t-sample test didapatkan bahwa hasil t-hitung $>$ dari t-tabel. Dimana berdasarkan jumlah populasi sebanyak 44 responden t-tabel dengan tingkat kepercayaan $5 \%(0,05)$ maka t-tabel $=2,000$ berarti semua indikator dalam penelitian ini dapat diteliti.

\section{Uji Hipotesis}




\section{P-ISSN: $2527-8479$ E-ISSN: 2686-2174}

1. Uji T-hitung terhadap T-tabel

Tabel 16. ANOVA

ANOVA ${ }^{b}$

\begin{tabular}{|ll|r|r|r|r|r|}
\hline \multicolumn{1}{|c|}{ Model } & Sum of & Squares & df & Mean Square & F & Sig. \\
\hline 1 Regression & 160.654 & 1 & 160.654 & 8.124 & $.007^{\mathrm{a}}$ \\
& Residual & 830.528 & 42 & 19.774 & & \\
\multicolumn{1}{l|}{ Total } & 991.182 & 43 & & & \\
\hline
\end{tabular}

a. Predictors: (Constant), Minat

b. Dependent Variable: Sikap

Berdasarkan nilai uji Anova pada nilai f maka nilai f-hitung $=8,124>$ f-tabel $(0,05)=$ 4,00 berarti sikap berpengaruh signifikan terhadap minat. Dengan demikian bahwa semakin baik atau semakin tinggi nilai sikap generasi millennial terhadap usaha tani maka semakin tinggi pula minat generasi millennial terhadap usaha pertanian, sebaliknya bila sikap generasi millennial semakin berkurang maka minat untuk melakukan usaha pertanian semakin kurang.

Tabel 17. Coefficients

\section{Coefficients $^{\mathrm{a}}$}

\begin{tabular}{|c|c|c|c|c|c|}
\hline \multirow[b]{2}{*}{ Model } & \multicolumn{2}{|c|}{$\begin{array}{c}\text { Unstandardized } \\
\text { Coefficients }\end{array}$} & \multirow{2}{*}{$\begin{array}{c}\begin{array}{c}\text { Standardized } \\
\text { Coefficients }\end{array} \\
\text { Beta }\end{array}$} & \multirow[b]{2}{*}{$\mathrm{t}$} & \multirow[b]{2}{*}{ Sig. } \\
\hline & B & Std. Error & & & \\
\hline (Constant) & 13.369 & 4.876 & & 2.742 & .009 \\
\hline Minat & .252 & .088 & .403 & 2.850 & .007 \\
\hline
\end{tabular}

a. Dependent Variable: Sikap

Berdasarkan analisis SPSS dengan melihat tabel nilai coefficients di atas untuk menguji hipotesis penelitian ini didapatkan bahwa nilai t-hitung $=2,850>\mathrm{t}$-tabel $(0,05)=$ 2,000 artinya bahwa sikap generasi milenial di Desa Lapodi berpengaruh signifikan terhadap minat dalam melakukan usaha pertanian. Dengan demikian bahwa semakin tinggi atau semakian baik sikap generasi milenial semakian tinggi atau baik pula minat generasi milenial umtuk melakukan usaha pertanian sebaliknya jika sikap generasi milenial rendah atau kurang baik maka minatnya terhadap usaha atau pekerjaan dibidang pertanian akan semakin rendah atau kurang baik.

2. Uji R-Square

Tabel 18. Model Summary

\begin{tabular}{l|r|r|r|r}
\hline \multicolumn{5}{c}{ Model Summary } \\
\hline Model & $\mathrm{R}$ & R Square & $\begin{array}{c}\text { Adjusted R } \\
\text { Square }\end{array}$ & $\begin{array}{l}\text { Std. Error of } \\
\text { the Estimate }\end{array}$ \\
\hline 1 & $.403^{\mathrm{a}}$ & .162 & .142 & 4.447 \\
\hline
\end{tabular}


a. Predictors: (Constant), Minat

Berdasrkan uji r-square didapatkan nilai $0,403 \%$ artinya bahwa minat dipengaruhi oleh sikap sebesar 40,3\% sedangkan sebesar 59,7\% dipengaruhi oleh variabel lain yang tidak ada dalam penelitian ini.

\section{Pembahasan}

1. Pengaruh Sikap Generasi Millennial Terhadap Minat Usaha Tani

Berdasarkan hasil uji hipotesis dan uji r-square dalam penelitian ini dapat dijelaskan beberapa hal yang berkaitan dengan sikap generasi millennial terhadap minat dalam melakukan usaha pertanian. Adapun hasil temuan dan dapat dijelaskan dalam penelitian ini adalah sebagai berikut:

a. Minat generasi millennial dalam melakukan usaha pertanian dipengaruhi oleh sikap seperti pengalaman, pendapatan, bantuan dan pendidikan.

b. Pengalaman generasi millennial dalam hal usaha pertanian sangat menentukan minat untuk melakukan usaha pertanian, dimana generasi millennial yang memiliki pengalaman yang cukup dalam hal pertanian cenderung akan melakukan kegiatan pertanian dengan harapan bahwa usaha pertanian dapat menunjang kehidupan keluarga dan masyarakat pada masa yang akan datang.

c. Sebahagian dari generasi millennial kurang berminat terhadap usaha pertanian disebabkan oleh pendapatan yang dihasilkan dari usaha pertanian sangatlah kurang akibatnya sikap generasi millennial terhadap usaha pertanian cenderung kurang baik dan menganggap bahwa bertani adalah pekerjaan yang tidak dapat menunjang pada masa yang akan datang. Hal ini terbukti saat ini generasi millennial lebih cenderung mencari pekerjaan yang tidak tetap ketimbang melakukan pekerjaan bertani bahkan sebagai masyarakat menganggap bahwa usaha pertanian adalah usaha alternatif terakhir bila tidak ada usaha lain.

d. Sebahagian dari generasi millennial dalam melakukan usaha tani cenderung berpikir bagaimana mendapatkan bantuan modal usaha dari pemerintah sehingga para millennial menggantungkan usahanya pada ada dan tidaknya bantuan pemerintah.

e. Sikap generasi millennial terhadap minat usaha tani sangat kurang disebabkan oleh pendidikan tentang pertanian sangatlah kurang sehingga mereka menganggap bahwa berprofesi sebagai petani adalah profesi yang kurang menjanjikan. Hal ini terjadi karena para penyuluh pertanian kurang aktif dalam hal menyosialisasikan produk usaha pertanian akibatnya masyarakat cenderung menganggap bahwa petani adalah pekerjaan yang kurang menguntungkan. Dengan Demikian pendidikan pertanian perlu didorong oleh semua pihak terutama para penyuluh pertanian karena pendidikan dan pemahaman usaha tani sangat dibutuhkan para petani millennial saat ini.

f. Generasi millennial kurang berminat terhadap usaha pertanian sehingga masyarakat menggantungkan kebutuhan hidup hidupnya pada pasar, dimana semua bahan pokok yang dibutuhkan akan ketergantungan dengan pasar, dengan kondisi demikian usaha pertanian cenderung diabaikan dan ini akan berakibat pada krisis pangan pada masa-masa yang akan datang. 
g. Kurangnya sikap baik generasi millennial terhadap minat usaha pertanian akan berakibat langkahnya bahan pokok masyarakat, ini dilihat dari total populasi generasi millennial di Desa Lapodi Kecamatan Pasarwajo Kabupaten Buton sebesar 788 oramng, namun generasi milenial yang melakukan kegiatan usaha tani hanya berjumlah 44 orang.

h. Pendidikan bagi generasi millennial terhadap usaha pertanian sangat dibutuhkan agar usaha pertanian terus meningkat.

\section{Minat Generasi Millennial Terhadap Usaha Pertanian}

Berdasarkan hasil penelitian minat generasi millennial dalam melakukan usaha pertanian di Desa Lapodi Kecamatan Pasarwajo Kabupaten Buton akan ditentukan oleh beberapa hal sebagai berikut :

a. Masyarakat millennial atau generasi millennial akan berminat melakukan usaha pertanian bila penghasilan yang didapatkan dari usaha tersebut berada di atas ratarata.

b. Minat generasi millennial dalam melakukan usaha pertanian dengan harapan untuk penyediaan bahan pokok sehingga beberapa generasi millennial memilih bertani karena dari sisi ketersediaan kebutuhan pokok dapat menjanjikan.

c. Generasi millennial yang belum memiliki lapangan pekerjaan menganggap bahwa bertani merupakan lapangan kerja baru yang perlu dimaksimalkan namun demikian hasil pertanian terkendala pada proses penjualan hasil-hasil pertanian, sehingga hasil petani hanya pada pemenuhan kebutuhan pokok tidak dapat dikembangkan pada pemenuhan kebutuhan oleh masyarakat umum.

d. Beberapa petani generasi millennial lebih memilih atau berminat terhadap usaha pertanian karena merasa bahwa menjadi petani tidak diatur oleh atasan, sehingga waktu bekerja dikelola oleh sendiri atau lebih dikatakan bahwa bebas memilih waktu kerja tanpa harus diatur atau ditekan orang lain.

e. Pada sisi perekonomian keluarga, minat usaha pertanian dapat menunjang perekonomian keluarga, karena hasil produksi pertanian dapat bernilai ekonomis, di sisi lain bila hasil produksi pertanian tidak dapat terjual maka akan berdampak pada kerugian pada usaha tani sehingga akan berakibat pada krisis atau kekurangan ekonomi.

f. Beberapa petani millennial yang ingin bertani terkendala pada lokasi pertanian, dimana saat ini dengan adanya patok kawasan hutan, berakibat pada sulitnya mendapatkan lahan pertanian oleh masyarakat karena itu berakibat pula pada terjadinya pinjam meminjam lahan kosong yang dimiliki oleh masyarakat namun hasilnya tidak maksimal karena lahan tersebut sewaktu-waktu akan diambil oleh pemiliknya.

g. Generasi millennial yang berminat melakukan usaha pertanian karena desakan ekonomi, sehingga usaha pertanian menjadi usaha terakhir untuk menunjang ekonominya, sehingga usaha pertanian dianggap sebagai usaha sampingan, hasilnya pun tidak maksimal atau hanya sebagai petani musiman yaitu musim barat saja ataupun musim timur saja. 


\section{KESIMPULAN DAN SARAN}

\section{Kesimpulan}

Dari hasil penelitian, peneliti menyampaikan beberapa saran sebagai berikut:

a. Sikap generasi millennial berpengaruh signifikan terhadap minat dalam melakukan usaha pertanian, hal ini dilihat dari hasil print out SPSS dimana $t_{\text {hitung }}=2,850>t_{\text {tabel }}$ $(0,05)=2,000$. Dengan demikian $\mathrm{H} 0$ ditolak dan $\mathrm{H} 1$ diterima yang menyatakan semakin tinggi sikap generasi millennial terhadap pertanian maka semakin tinggi pula minat generasi millennial untuk melakukan usaha pertanian.

b. Sikap generasi millennial dengan indikator pengalaman, pendapatan, bantuan dan pendidikan akan berakibat pada minat generasi millennial dalam hal melakukan usaha pertanian.

c. Pengaruh sikap generasi millennial terhadap minat usaha pertanian sebesar $40,3 \%$ sedangkan sebesar 59,7 \% dipengaruhi oleh faktor lain yang tidak terdapat dalam model penelitian ini. Dengan demikian bahwa faktor sikap generasi millennial terhadap minat usaha pertanian hanya sebesar 40,3\%. Sedangkan sisanya bisa dilanjutkan dengan penelitian dengan variabel dan indikator lain.

d. Semua indikator dan sub indikator dalam penelitian ini saling mempengaruhi dan saling bersilangan sehingga tingkat keakuratan dalam penelitian sebesar $95 \%$ dan nilai error dari penelitian ini sebesar $5 \%$.

e. Hasil penelitian ini menujukan bahwa dari semua indikator sikap, pengalaman dan pendidikan memiliki nilai yang cukup tinggi atas jawaban responden yaitu pengalaman sebesar 3,77 dan pendidikan sebesar 3,95 artinya bahwa dalam berusaha tani, petani millennial membutuhkan suatu pengalaman, serta membutuhkan pendidikan yang memadai.

\section{Saran}

Dari hasil penelitian, peneliti menyampaikan beberapa saran yaitu sebagai berikut:

a. Generasi millennial adalah generasi penerus bangsa yang minat dan potensinya perlu dimaksimalkan dan dimanfaatkan dengan sebaik-baiknya demi peningkatan perekonomian bangsa ini.

b. Pertanian merupakan urat nadi dari kehidupan masyarakat sehingga para pemangku kepentingan perlu mendorong usaha pertanian agar para generasi millennial tidak gengsi terhadap usaha pertanian, karena kehidupan manusia akan bergantung pada ketersediaan bahan pokok terutama pangan dan bahan pokok tersebut berasal dari pertanian.

c. Para penyuluh pertanian atau Dinas Pertanian diharapkan lebih intents masuk di masyarakat agar memberikan motivasi dan penyuluhan pertanian kepada masyarakat untuk selalu bertani dengan baik dengan cara-cara yang baik agar memiliki nilai ekonomi yang tinggi, sehingga bukan hanya sekadar mencukupi kebutuhan dasar.

d. Pemerintah harus menyediakan pangsa pasar produk pertanian masyarakat sehingga hasil pertanian dapat meningkatkan kehidupan ekonomi masyarakat.

e. Agar dilakukan penelitian lebih lanjut mengenai sikap generasi millennial terhadap minat usaha pertanian dengan tambahan variabel ataupun indikator dan sub indikator sehingga hasil penelitian selanjutnya akan lebih kompleks dan simultan karena pengaruh dua variabel ini hanya sebesar 40,3 persen. 


\section{P-ISSN: 2527-8479 E-ISSN: 2686-2174}

\section{DAFTAR PUSTAKA}

Andryani, Santi. 2013. Minat Kerja Mahasiswa Program Studi Pendidikan Teknologi Agroindustri FPTK UPI. Repository.upi.edu

Agustina, Shinta, 2011. Ilmu Usaha Tani. books google.co.id

Arikunto. S., 2006. Prosedur Penelitian Suatu Pendekatan Praktik. PT. Rineka: Jakarta

Azwar S, 2012. Tinjauan Pustaka. digilib.unila.ac.id.pdf.II.

Darmawan R, 2015. Bab II Landasan Teori A. Tinjauan Pustaka 1. Minat .http://eprints.ums.ac.id/35501/9/BAB\%20II.pdf.

Darmadi. H, 2017. Pengembangan Model dan Metode Pembelajaran Dalam Dinamika Belajar Siswa. books google.co.id.

Hanafi, Halid, Adu L, Muzakkir H, 2018. Profesionalisme Guru Dalam Pengelolaan Kegiatan Pembelajaran Di Sekolah. books google.co.id.

Hidayatullah S, Waris A, Devianti R.C, Sari S.R, Wibowo A.I, Made P.P.W.2018. Perilaku Generasi Milenial dalam Menggunakan Aplikasi Go-Food. Jurnal Manajemen Kewirausahaan.

Huda. F.A. 2017. Teknis Pengumpulan data dan analisis dalam penelitian. http://fatkhan.web.id/teknik-pengumpulan-data-dan-analisis-dalam-penelitian.

Jurnal Ilmiah Pendidikan Mipa, 2012. Pengaruh Minat Dan Kebiasaan Belajar Siswa Terrhadap Prestasi Belajar Matematika.

Kementerian Pemberdayaan Perempuan Dan Anak, Badan Pusat Statistik. 2018. Statistik Gender Tematik: Profil Generasi Milenial Indonesia.www.kemenpppa.go.id > lib > list > 9acde-buku-profil-generasi-milenia.

Mc Clave J.T, Bendon P.George, Sincich Terry.2010. Statistik Untuk Bisnis dan Ekonomi (Terjemahan).PT.Gelora Aksara Pratama : Erlanga. Jakarta

Nurdin N, 2019. Generasi Emas Santri Zaman Now. books google.co.id

Panurat S.M ; 2014. Faktor-Faktor Yang Mempengaruhi Minat Petani Berusaha tani Padi Di Desa Sendangan Kecamatan Kakas Kabupaten Minahasa.

PerumBulog. 2018. Beras dan Ketahananpangan. www.bulog.co.id.

Putra. S.P. 2016.Teori Perbedaan Generasi. https://jurnal.stieama.ac.id 


\section{Media Agribisnis}

Vol. 4, Issue 2, November 2020

\section{P-ISSN: 2527-8479 E-ISSN: 2686-2174}

Putri A.A.K.S, 2008. Analisis pengaruh sikap generasi milineal terhadap Minat beli online pada situs jejaring sosial.Tesis

Putu N.L, Dewi R, Utama MS, Yuliarmi NN, 2017. Faktor-Faktor Yang Mempengaruhi Produktivitas Usaha Tani Dan Keberhasilan Program Simantri Di Kabupaten Klungkung. E-Jurnal Ekonomi dan Bisnis Universitas Udayana

Reksoatmojo.T.N. 2009. Statistika untuk Psikologi dan Pendidikan, Bandung: PT Refika Aditama

Silalahi.T.S, et,al, 2019.Pemuda Milenial. books google.co.id

Sugiyono. 2010. Metode Penelitian Pendidikan Pendekatan Kuantitatif, kualitatif, dan R\&D.Alfabeta. Bandung

Undang-Undang Nomor 20 Tahun 2003 Tentang Sistem Pendidikan Nasional

Wimatsari A.W, Hariadi.S.S, Martono.E. 2019. Sikap Pemuda Desa Terhadap Usaha tani Salak Organik dan Pengaruhnya Terhadap Minat Berusaha tani Salak Organik. Journal of Agribusiness

Widarjono. Agus. 2010. Analisis Statistika Multivariant Terapan.upp STIM YKPN: Yogyakarta. 